\title{
Return on Assets and Capital Adequacy of Banks in Nigeria.
}

\author{
Apere, ThankGod Oyinpreye \\ Department of Economics, Niger Delta University \\ Wilberforce Island, Bayelsa State
}

\begin{abstract}
This research empirically investigated the relationship between Capital Adequacy of banks and Return on Assets of banks in Nigeria over the period 2001 to 2014.Using secondary data obtained from the Central Bank of Nigeria (CBN) statistical bulletin (2014) and World Bank (2015). Relevant econometric techniques were adopted in analysing the data for this study. Firstly the Descriptive Statistic test was conducted; Correlation test was also conducted to ascertain the strength of their relationship and it was observed that all the variables were stationary at their first differences, using the Phillip-Perron unit root test, and having determine the stationarity of the variables we further employ the Johansen Cointegration test, the Error Correction Model (ECM). The study revealed that there is a long-run significant positive relationship between capital adequacy and return on assets of banks in Nigeria over the period under review. This study therefore recommends that monetary authorities such as NDIC and CBN through their supervisory role should ensure that banks have enough capital so as to achieve increasing public confidence in the Nigerian banking sector thereby bringing increase returns on assets of the banks in particular and the financial sector in Nigeria.
\end{abstract}

Keywords: Financial System, Return on Asset, Capital Adequacy, Monetary Authorities,

\section{INTRODUCTION}

The banks and other financial institution (BOFID) degree no. 25 of 1991 defined a bank as any person or body of persons, institutions that is involved in the business of banking such as receiving deposits on current account, savings account or other similar accounts, paying or collecting cheques, drawn or paid in by customers, provision of finance lending or such other business as the government may by order published or by Gazette designate as banking business (Eniekezimene 2011). The history of bank failure in Nigeria dates back to 1930. Between 1947 and 1952, twenty-one out of the twenty five indigenous banks in the country collapsed. In 1959 alone 16 banks failed in Nigeria. The distress recorded in the 1990's was the most serious in terms of depth and the extent of its impact on financial system and the economy. The number of distressed bank was only 8 in 1990. However, this figure rose to 24 in 1993 and 60 in 1995. By the end of December 1995, 52 percent of the licensed banks were adjudged to be technically insolvent. The bank failures within these periods have been suggested by empirical evidence to have been caused by banks internal factors especially liquidity, profitability measured by the level of credits risk in a bank's portfolio (Eniekezemene 2011).

According to Nzotta (2004), to a very large extent, the strength of a bank depends on the capital funds available to it. A bank's capital can be defined as the equity value of a bank equated to the present value of its future net earnings. Banks capital boost public confidence and assures the public that depositors' funds are safe, that the bank can accommodate the credit needs of the community, it serves as a means of assessing the strength of a bank, it assures the regulatory bodies that the financial system is not threatened or weakened by any 
crises in a single bank or group of banks. Bank capital also ensures the safety of a bank, it helps the bank to avoid the risk of insolvency, and also to support the credit risk a bank is called upon to assume in a normal business leading. Here, the larger the capital resources, the more loans and advances the bank could grant both on the aggregate and for single individuals. A bank's capital resources help the supervisory authorities in assessing the adequacy of its capital in relation to its loans and investments. Many regulators believe ROA is the best measure of bank profitability (Hassan and Bashir, 2003). Rivard and Thomas (1997) suggest that bank profitability is best measured by ROA in that ROA is not distorted by high equity multipliers and ROA represents a better measure of the ability of the firm to generate returns on its portfolio of assets. ROA gives an idea as to how efficient management is at using its assets to generate earnings. Calculated by dividing a company's annual earnings by its total assets, ROA is displayed as a percentage. Sometimes this is referred to as "return on assets". Banks performance in terms of profitability is largely determined by it Capital adequacy. This research work, attempts to assess and appraise the impact of capital adequacy and return on asset as a proxy for banks profitability.

\section{Theoretical Framework}

\section{LITERATURE REVIEW}

Portfolio theory was first published by Fischer Black and Myron Scholes in 1973. The use of a portfolio approach enables us to define capital adequacy. We would like to be able to measure adequate capital in a way that could be used by managers, insurers, and regulators. Such a task is not simple; if it were, no special studies would be needed. Our experience shows that modern theories of finance enable us to define and model capital adequacy. The measurement problem, while not easy, does not appear more difficult than those solved else- where. Applications of known techniques allow us to clarify any problems and to arrive at preliminary estimates of the magnitudes of some of the key parameters. What constitutes adequate capital depends upon the amount of risk assumed by a firm. Capital is adequate either when it reduces risk of future insolvency to some predetermined level or when the premium paid by the bank to an insurer is "fair"; that is, it covers the expected losses of the insurer, given the risk and capital of the firm and the terms of insurance with respect to when insolvency will be determined and what losses will be paid (Maisel, S.J. 1978).

Portfolio theory supplies the necessary tools for measuring the risks of insolvency. A bank selects a portfolio consisting of a variety of particular activities, including assets, liabilities, commitments, non balance-sheet operations, and net worth (capital and reserves). The expected changes in these activities, their rate of return, and the bank's capital policy give an expected end-of-period net worth. However, expectations are unlikely to be realized exactly. Because of economic events, total income (including changes in capital values) will exceed or fall short of expected levels. (Markowitz, 1959; Sharpe, 1964; Lintner, 1965; Mossin, 1966; Merton, 1974, 1977). Measuring the risk of a portfolio requires a calculation of its expected end- of-period net worth and of the probable distribution of possible net worth's around this level. The bank will become insolvent if events cause its income to be so negative as to more than offset its initial capital plus any contributions less any dividends paid during the period. Risk depends on both the probability of insolvency and the expected losses in case of such failure. Capital is risk-offsetting because it can cover losses. It can bridge negative cash flows and pay off creditors. It also earns returns, but does not require cash payments or engender interest-rate risk. Yet banking history reflects a steady decline in the ratio of capital to assets. Why has this occurred? Why has leverage-the ratio of borrowed money to capital - steadily increased? Financial theory offers two conflicting answers. One emphasizes the advantages to stockholders of increasing leverage, advantages to be gained because of the tax and regulatory 
system. While, in theory, arbitrage among investors and lenders should wipe out any profits from leverage, this probably does not happen under existing conditions.

In contrast, traditional theory posits a falling cost curve until leverage reaches some optimum point. It pays to reduce the capital ratio until that point is reached. If leverage continues to expand among banks, this indicates that the market judgment is that leverage has not reached an optimum. In this latter view, failure to pick the optimum point of capital reduces welfare through a waste of scarce resources. On the other hand, if leverage has expanded primarily because it is subsidized by the government, then regulations which prevent it from expanding as far as the market wants do not create a social loss. While neither view can be proved, many believe that bank capital may be far lower now than it would be in a completely free, competitive market. In banking, unlike other industries where excess capital and fixed assets are wasted, most capital is lent out. There are no obvious advantages to substituting one form of liquid capital for another; in contrast to whatever ratio a free market would select (Maisel, S.J. 1978).

Banks play a pivotal role in the shaping up of the economy of a country, given the relationship between the well being of the banking sector and the growth of the economy (Rajan and Zingales 1998; Cetorelli and Gambera 2001; Beck and Levine 2004). The knowledge that capital adequacy influences the financial sector's profitability is essential not only for the managers of banks, but for numerous stakeholders such as the central banks, bankers associations, governments, and other financial authorities. Bobakova, (2003), states that capital influences bank profitability, argues that in the arithmetical sense, the yield on own capital grows ceteris paribus as the capital proportion declines, since a given volume of capital supports a higher volume of assets A bank with adequate capitalization will surely gain more public confidence than a poorly capitalized. Yu Min-The (2006), defined the adequate capital for banks as the level at which the deposit insuring agency would breakeven in guaranteeing the deposits of individual banks with premium the banks pay. An option of theoretical framework was employed in his study for measuring fair capital adequacy holdings for a sample of depository institutions in Taiwan, during 1985-1992. Except for the 1989, most banks in their sample proved to be inadequately capitalized so that capital infusion is required. Banks performance is measured by its capacity to maximize returns on investor's funds. In the Nigerian economy bank performance is determined by a number of factors, namely lending rates, deposit rate, management effect, ownership and control, market structure etc (Somoye \& Ilo, 2009).

\section{Empirical Review}

Ngo (2006), attempted to find out the effect of Endogenous Capital and Profitability in Banking. He investigated the relationship between bank capital and profitability. According to his study and to the best of his knowledge, no previous paper had analyzed the problem in a twoequation structural model. Contrary to what is often reported with surprising frequency in this field of research, his results showed no statistically significant relationship between capital and profitability. Given non-binding capital requirements his finding was consistent with the view that, while raising capital is costly for banks, it is associated with compensating benefits that offset these additional costs. Consequently, when capital structure is endogenously determined in a profit maximizing equilibrium, no systematic relationship between capital and profit is expected. 
Akintoye and Somoye (2008) argued in favour of few banks with adequate capital suggesting further soiling up of banks capital base. This view is further radically and specifically approached in the proposition of Alao (2010) that suggested minimum capital base of 300 billion naira and reduction in the number of banks to three. Noticeable movement in this direction was the merger talks among the various banks and more specifically of the first bank plc and Zenith plc believed to be the two giant banks in Nigeria. The extent to which the merger talks suspected to be as a result of bail out strategy by the Nigerian government, will make for further reduction in the number of banks in Nigeria, has created concerns for players in the industry. According to Somoye (2008) from 1952-1978, the banking sector recorded forty five (45) banks with varying increase in the minimum capital. The number of banks dropped to one hundred and ten (110) with another increase in minimum paid-up capital and finally dropped from 89 as at end of 2003 to 25 in 2006 with a big increase in minimum paid-up from 2 billion naira in January 2004 to 5billion in July 2004. As at the end of 2010, the number of banks that are licensed to practice in Nigeria was 24. Alao (2010) conducted investigation on the Nigerian twenty five (25) mega banks recommending further shrink to only almighty three mega banks with recapitalization of 300 billion naira capital base with two years ultimatum. According to the study, only one best emerged from multifarious performance ratings and world class tests to be conducted by CBN after fulfilling the requirement of \#300billion base will represent the existing Nigerian 25 banks.

George and Dimitrios (2004) applied non-parametric analytic technique (data envelopment analysis, DEA) in measuring the performances of the Greek banking sector with respect to capital adequacy. He proved that data envelopment analysis can be used as either an alternative or complement to ratio analysis for the evaluation of an organization's performance with attention to macroeconomics indicators. Various studies suggest that banks with higher levels of capital perform better than their undercapitalized peers. Staikouras and Wood (2003) claimed that there exists a positive link between a greater equity and profitability among EU banks. Abreu and Mendes (2001) also trace a positive impact of equity level on profitability. Goddard et al. (2004) supports the prior finding of positive relationship between capital/asset ratio and bank's earnings.

Demirguc-Kunt and Huizinga (1999) conducted a more comprehensive study which examined the determinants of banking performance for 80 countries, both developed and developing, during the period 1988- 1995. They concluded that foreign banks have higher profitability than domestic banks in developing countries, while the opposite holds in developed countries. Nevertheless, their overall results showed support for positive relationship between the capital ratio and financial performance. Flamini, Calvin and Liliana (2009) used a sample of 389 banks in 41 SSA countries to study the determinants of bank profitability. They found out that apart from credit risk, higher returns on assets are associated with larger bank size, activity diversification, and private ownership. Bank returns are affected by macroeconomic variables, suggesting that macroeconomic policies that promote low inflation and stable output growth do boost credit expansion. Their results also indicated moderate persistence in profitability. Causation in the Granger sense from returns on assets to capital occurs with a considerable lag, implying that high returns are not immediately retained in the form of equity increases. Thus, their paper gave some support to the policy of imposing higher capital requirements in the region in order to strengthen financial stability. At last, it was the conclusion of their study that, bank profits are high in Sub-Saharan Africa (SSA) compared to other regions 
Aburime (2009) examined the determinants of profitability of 33 Nigerian banks from 2000 to 2004 with particular reference on company level. The result shows capital size, credit portfolio and ownership concentration were significantly related to bank profitability.

Vong and Anna (2009) examined the impact of bank characteristics as well as macroeconomic and financial structure variables on the performance of the banking industry. The results showed that the capital strength of a bank is of paramount importance in affecting its profitability. A well-capitalized bank is perceived to be of lower risk and such an advantage will be translated into higher profitability. On the other hand, the asset quality, as measured by the loan-loss provisions, affects the performance of banks adversely. In addition, banks with a large retail deposit-taking network do not achieve a level of profitability higher than those with a smaller network. Finally, with regard to macroeconomic variables, their study revealed that only the rate of inflation exhibits a significant relationship with banks' performance.

\section{METHODOLOGY AND DATA.}

The ordinary least square (OLS) technique is adopted in this study. However, in the attempt to establish the impact of adequate bank capital on return on asset as a proxy for performance and profitability of banks in Nigeria; a linear equation is estimated, since the evaluation considers long-run. In order to undertake the empirical analysis using the OLS technique, the variables involved in the model must be stationary and integrated of the same order (see Nelson \& Polser 1982; Stock \& Watson 1988; and Campbell \& Perron 1991). Thus the PhillipsPerron (PP) (1988) unit root tests were utilized to test for stationarity and the order of integration of the variables, the descriptive statistic test was also employed coupled with correlation test to ascertain the strength of the relationship of the variables, cointegration to ascertain long run relationship among the variables integrated at the same order, the error correction model (ECM) test was also conducted. This study employed time series secondary data spanning from 2001 to 2014. This period is chosen due to the availability of data. The relevant data were collected from the Central Bank of Nigeria Statistical Bulletin, 2014 edition and Word Bank data base, November 2015. Data collected include Return on Asset (ROA), Capital Adequacy Ratio (CAR), Non-Performing Loan Ratio (NPL), Liquidity Ratio (LR) and Inflation (INFL).

\section{Model Specification}

The model specified below is used in order to analyze the impact of Bank Capital Adequacy (CAR) on Return on Asset (ROA), This study specifically employ simple regression analysis with OLS econometric technique for data analysis to empirically verify whether a significant relationship exists between the dependent variables (return on asset), and the independent variables (capital adequacy ratio, non-performing loan ratio of banks, liquidity ratio and inflation) in Nigerian.

Firstly the model that captures the impact of capital adequacy on return on asset is specified thus:

$R O A=f(C A R, N P L, L R, I N F L)$

Equation (3.1) can be rewritten in Econometric linear form thus:

$\mathrm{ROA}=\delta 0+\delta 1 \mathrm{CAR}+\delta 2 \mathrm{NPL}+\delta 3 \mathrm{LR}+\delta 4 \mathrm{INFL}+\varepsilon \mathrm{t}$. 
Where: $\mathrm{ROA}=$ Return on Asset; CAR = Capital Adequacy ratio; LR=Liquidity Ratio; NPL = Nonperforming loan; INFL=Inflation Rate

$\delta 0=$ Autonomous ROA when capital adequacy ratio, non-performing loan ratio, liquidity ratio and inflation rate are held constant.

$\delta 1-\delta 4=$ Coefficient of the independent variables, $\varepsilon \mathrm{t}=$ Error term.

RESULT AND DISCUSSION

Empirical results of this research is presented in the tables and discussed below:

Table 4.1: Descriptive Statistics

\begin{tabular}{|l|l|l|l|l|l|}
\hline Variables: & ROA & CAR & NPL & LR & INFL \\
\hline Mean & 0.044652 & 11.33000 & 15.25000 & 47.05000 & 12.02143 \\
\hline Median & 1.479231 & 10.76000 & 19.10000 & 49.50000 & 11.70000 \\
\hline Maximum & 3.027379 & 17.70000 & 37.30000 & 63.20000 & 23.80000 \\
\hline Minimum & -18.16000 & 1.490000 & 3.400000 & 30.40000 & 6.600000 \\
\hline Standard deviation & 5.419053 & 4.859022 & 10.06683 & 9.177795 & 4.413646 \\
\hline Observations & 14 & 14 & 14 & 14 & 14 \\
\hline
\end{tabular}

Source: Author's computation.

The empirical evidence in Table 4.1: represents the descriptive statistics of the first model. From the result ROA is a dependent variable, while CAR, NPL LR and INFL are the independent variable. The sample size comprises of 14 observations from the period of 2001 to 2014. The minimum and maximum value of ROA (-18.16000) \& (3.027379) respectively, showing an increase in banks returns to assets from $-18 \%$ in 2001 to $30.0 \%$ in 2014 with an average value of (0.044652) and standard deviation of (5.419053). The minimum and maximum value of CAR (1.490000) \& (17.70000) respectively, indicating an increase in the adequacy of capital of banks in Nigeria from $1.50 \%$ to $17.70 \%$ over the period under review; with a mean value of (11.33000) and standard deviation of (4.859022). NPL having minimum value (3.400000), maximum value of (37.30000), whereas the mean value is (15.25000) and standard deviation is (10.06683). The minimum and maximum value of LR (30.40000) \& (63.20000) respectively, whereas the mean value is (47.05000) and standard deviation is (9.177795). The minimum and maximum value of INFL (6.600000) \& (23.80000) respectively, whereas the mean value is (12.02143) and standard deviation is (4.413646).

Table 4.2: Correlation Test Result

\begin{tabular}{|l|l|l|l|l|l|}
\hline Variables & ROA & CAR & NPL & LR & INFL \\
\hline ROA & 1.000000 & 0.510123 & 0.590763 & 0.607282 & 0.108132 \\
\hline CAR & 0.510123 & 1.000000 & 0.360141 & 0.527206 & 0.275823 \\
\hline NPL & 0.590763 & 0.360141 & 1.000000 & 0.273947 & 0.408814 \\
\hline LR & 0.607282 & 0.527206 & 0.273947 & 1.000000 & 0.061365 \\
\hline INFL & 0.108132 & 0.275823 & 0.408814 & 0.061365 & 1.000000 \\
\hline
\end{tabular}

Source: Author's computation.

The correlation result reveals that positive correlations exist among all the variables used in the study; with positive relationship between the dependent variable (ROA) and the independent variables (CAR, NPL, LR and INFL). The result shows that ROA exhibited a positive correlation of $51 \%$ with CAR, $59 \%$ with NPL, showing $61 \%$ correlation with LR and a very low relationship with INFL. 
Most macroeconomics variables data are found non stationary, as such finding drawn from regression analysis with such variables (integrated in different order) proceeds non sense or spurious regression. Thus it is essential to analysis the stationarity of the data employed in this study, before ascertaining the long run association among the variables.

Table 4.3: Phillip-Perron Unit Root Test

\begin{tabular}{|lcccccc|}
\hline Variable & Level & First difference & Second Difference & Lag(s) & Model Order of integration \\
\hline ROA & -2.648289 & $-7.610498^{* * *}$ & 1 & Trend \& Intercept & I(1) \\
CAR & -2.292847 & $-4.786639^{* *}$ & 1 & Trend \& Intercept & I $(1)$ \\
NPL & -3.578414 & $-6.710297 * * *$ & 1 & Trend \& Intercept & I(1) \\
LR & -0.739948 & $-2.959853^{* * *}$ & 1 & Trend \& Intercept & I $(1)$ \\
INFL & -3.813611 & $-8.314821^{* * *}$ & 1 & Trend \& Intercept & I $(1)$ \\
ECM(-1) $-3.582497^{* * *}$ & & 0 & None & I $(0)$ \\
\hline
\end{tabular}

Source: Author's computation.

Note: $\left.{ }^{* *}\right)^{* * *}$ denotes statistically significant at $1 \%, 5 \%$ and $10 \%$ level respectively. This test is carried out to avoid the estimated regression being spurious. Whenever a non-stationary time series is regressed on another or other non-stationary time series, the result is always a spurious regression result.

The Phillip-Perron stationarity test in table 4.1 shows that, ROA, CAR, NPL, LR, and INFL are all non-stationary at level as such have unit root problem at their ordinary level form. But all other variables are stationary at their first difference. Thus this is in consonance with the fact that most macroeconomic variables are stationary at their first difference (stationary at 1\%, $5 \%, 10 \%$ level respectively). Since all the variables are integrated at order one, i.e., 1(1), and the generated residual is stationary at level, then employing the popular Johansen Cointegration Rank test will help us to determine the number of Co-integrating equations in the Error Correction Model (ECM) and thus confirm if there is long-run relationship among the variables in their linear combination; using the variables integrated at the same order.

Table 4.4: Johansen cointegration Test Result

\begin{tabular}{|c|c|c|c|c|}
\hline \multicolumn{5}{|c|}{ Unrestricted Cointegration Rank Test (Trace) } \\
\hline $\begin{array}{l}\text { Hypothesized } \\
\text { No. of CE(s) }\end{array}$ & Eigenvalue & $\begin{array}{c}\text { Trace } \\
\text { Statistic }\end{array}$ & $\begin{array}{c}0.05 \\
\text { Critical Value }\end{array}$ & Prob. $* *$ \\
\hline None $*$ & 0.862528 & 45.67915 & 42.91525 & 0.0258 \\
\hline At most 1 & 0.642200 & 21.86710 & 25.87211 & 0.1455 \\
\hline At most 2 & 0.548183 & 9.533737 & 12.51798 & 0.1499 \\
\hline \multicolumn{5}{|c|}{$\begin{array}{l}\text { Trace test indicates } 1 \text { cointegrating eqn(s) at the } 0.05 \text { level } \\
* \text { denotes rejection of the hypothesis at the } 0.05 \text { level } \\
* * \text { MacKinnon-Haug-Michelis }(1999) \text { p-values }\end{array}$} \\
\hline
\end{tabular}

Source: Author's computation 
To determine the number of cointegrating equation, the results of the trace statistic in table 4.4 indicate one (1) Co-integrating equations at 5\% level. This shows the possibility that the variables are co-integrated. That is, there exists a long-run or equilibrium relationship among the variables employed in the model. Having confirmed the fact that all the 1(1) variables are co-integrated, we proceed to estimate the error correction model (ECM) for which results are presented in table 4.5

Table 4.5: Regression Results

Dependent Variable: D(ROA)

Included observations: 13 after adjustments

\begin{tabular}{crcrr}
\hline \hline Variable & Coefficient & Std. Error & t-Statistic & Prob. \\
\hline \hline C & -47.03619 & 11.18769 & -4.204283 & 0.0040 \\
D(CAR) & 0.384111 & 0.185899 & 2.066230 & 0.0776 \\
D(NPL) & -0.227391 & 0.074623 & -3.047216 & 0.0187 \\
D(LR) & -12.17701 & 2.928681 & -4.157850 & 0.0043 \\
D(INFL) & 0.140873 & 0.090188 & 1.561995 & 0.1623 \\
ECM(-1) & -0.181617 & 0.212173 & -0.855984 & 0.4203 \\
\hline \hline & 0.944400 & Mean dependent var & -0.183851 \\
R-squared & 0.904685 & S.D. dependent var & 5.569686 \\
Adjusted R-squared & 1.719537 & Akaike info criterion & 4.226024 \\
S.E. of regression & 20.69764 & Schwarz criterion & 4.486770 \\
Sum squared resid & -21.46916 & Hannan-Quinn criter. & 4.172429 \\
Log likelihood & 23.77965 & Durbin-Watson stat & 2.272705 \\
F-statistic & 0.000294 & & \\
Prob(F-statistic) & \multicolumn{2}{l}{} \\
\hline \hline
\end{tabular}

Source: Author's computation.

Table 4.5 shows a regression result of impact of capital adequacy on banks return on asset in Nigeria. As specified above, the results were obtained using the ECM and the Ordinary Least Square (OLS) method of estimation. From the empirical evidence the error correction results above show that about $18 \%$ of the disequilibrium errors accumulated in the previous period has been corrected in the current period. The error correction term which tells us the speed with which our model returns to equilibrium indicates that there is a significant adjustment of return on asset one period later to equilibrium, and the speed of adjustment or level of convergence is-0.181617. The ECM (-1) coefficient conforms to a priori expectation as its sign is negative, and less than unity in absolute terms. These estimates confirmed the long-run equilibrium condition evidenced among the variables included in the model and it further suggests that 18 percent of disequilibrium within a year is corrected for while the remaining 82 percent are corrected for in the following year.

The result indicates that capital adequacy of banks (CAR) have significant positive impact on (ROA) in Nigeria. From the result, the difference in sigma coefficient of the variables representing the contributions of capital adequacy of banks; it shows the different contributions of the variables to the profitability of banks which is been represented by banks return on assets (ROA). In this result, using the sigma coefficient, ROA is a negative of constant -47.03619. This means that when all variables are held constant, there will be a negative variation up to the tune of -47.03619 units in ROA. Similarly, a unit change in CAR when all variables are held constant will lead to an increase in ROA by 0.384111 percent; and from the result capital adequacy impact positively and significantly on return on asset of banks in Nigeria; thus the capital strength of a bank is of paramount importance in affecting its profitability. This is in conformity with the findings of Vong and Anna (2009) Bourke (1989), 
Berger (1995), Anghazo (1997), Molyneux and Thornton (1992), Demirguc-Kunt and Huizinga (1999), who all concluded that there exist a positive significant impact of capital adequacy on banks' profitability. However, a unit change in NPL based on its coefficient $(-0.227391)$ from the result is negative and statistically significant and will produce a negative impact on return on asset of banks in the Nigerian economy. In that a unit changes in NPL when all variables are held constant, will cause ROA to decrease by 0.227391 percent. In this result, LR is negative and statistically significant with a coefficient -12.17701 . This implies that a unit increase in LR when all variables are held constant will lead to a decrease in ROA by 12.17701 percent. While inflation rate (INFL) has a negative but not statistically significant impact on ROA. From the result a unit increase in inflation will cause return on asset to decrease by 0.140873 .

The adjusted R2 obtained is 0.904 . This shows that the explanatory variables included in our model accounts for 90.4 percents variations in return on asset of banks in Nigeria while the remaining 9.6 percent unexplained variations is due to other extraneous factors that are also necessarily accounts for the movement in return on asset of banks in Nigeria which is explained by the stochastic term. The implication is that the models do not suffer from any misspecification error. Complementing this is the F-ratio statistics with 23.779 with probability values of 0.000 . This is highly significant at the 5 percent levels; thus, giving credence to the conclusion that the entire model has goodness of fit. , as also shown by the R2 of 0.944 More so, the Durbin Watson (DW) statistics of 2.27 imply that the model is free from autocorrelation or serial correlation problem.

\section{CONCLUSION AND RECOMMENDATIONS}

This research is aimed to determine the relationship between return on asset and capital adequacy of banks in Nigeria using a linear regression analysis to test the relationship. Empirically the result of this study shows that capital adequacy has a positive and significant impact on banks return on assets in the Nigeria banking sector. The NPL ratio has a negative significant impact on the return on asset meaning that banks with higher credit risk have lower level of capitals. The LR ratio has a positive and significant impact on return on asset in the Nigeria banking industry The INFL rate has a negative impact on return on asset of banks in Nigeria; The empirical findings of this study is in conformity with the findings of Kosmidou, (2007); Gul, Irshad and Zaman (2011). The strength of a bank depends on the capital funds available to it; thus, capital adequacy plays a fundamental role in banks return on assets in the Nigeria banking sector. This study therefore recommends that monetary authorities such as NDIC and CBN through their supervisory role should ensure that banks have enough capital so as to achieve increasing public confidence in the Nigerian banking sector thereby bringing increase returns on assets of the banks in particular and the financial sector in Nigeria.

\section{Refferences}

Abreu, M. \& Mendes, V. (2000). “Commercial Bank Interest Margins and Profitability: Evidence for Some EU Countries". Paper presented on the 50th International Altantic Economic Conference, March 14.

Aburime, U. (2009). Determinants of bank profitability: company level evidence from Nigeria. [Online] Available: http://www.ssrn.com/abstract=1231064 (December 18, 2015).

Akintoye I.R and Somoye R.O.C (2008). Corporate conference and the get activity in the Nigerian Banking Industry.

Alao, rasheed olajide (2010) mergers and acquisitions (M \& As) in the Nigerian banking: an advocate of three mega banks European journal of social sciences - vol 15 no 4554

Angbazo, L. (1997). “Commercial bank interest margins, default risk, interest rates, and off -balance sheet banking". Journal of Banking and Finance, 21, 55-77 
Beck, T. and Levine, R. (2004). Stock market, banks and growth: Panel evidence. Journal of Banking and Finance, $28,423-442$.

Berger, A. N. 1995. "The Profit-Structure Relationship in Banking Test of Market Power and Efficient-Structure Hypothesis, Journal of Money, Credit and banking”. pp. 405.

Bobakova, I.V (2003): „Raising the profitability of Commercial Banks“ BIATEC, Volume XI, pp 21-25

Bourke, P. 1989. "Concentration and other determinants of bank profitability in Europe, north America and Australia, Journal of Banking and Finance". Vol. 13, pp 65-79.

Central Bank of Nigeria 2014. "Central Bank of Nigeria Statistical Bulletin”. Abuja: Central bank of Nigeria.

Cetorelli, N. and Gambera, A. (2001). Banking marketing structure, financial dependence and growth: International evidence from industry data. Journal of Finance, 56, 617-648.

Demirgüç-Kunt, A. \& Huizinga, H. (1999). “Determinants of Commercial Banks Interest Margins and Profitability: Some International Evidence”. World Bank Economic Review,13, pp. 379-408.

Eniekezimene, F.A. (2011). Financial Institutions, Markets and Instruments(1sted.). Port-harcourt: Harey Publications Coy

Flamini, V., Calvin, M. \& Liliana S. (2009). “The Determinants of Commercial Bank Profitability in Sub-Saharan Africa, 2009 International Monetary Fund Working Paper”, Vol 15, pp1-33

George, E. H. and Dimitrios, S. S. (2004). Efficiency measurement of the Greek commercial banks with the use of financial ratios: A data envelope analysis approach. Management Accounting Research, 15(2), 201-224.

Goddard, J., Molyneux, P., and Wilson, J.O.C. (2004). The profitability of European banks: A cross sectional and dynamic panel analysis. The Manchester School, 72 (3), 363-381.

Gul S, Irshad F, Zaman K (2011). Factors Affecting Bank Profitability in Pakistan, Romanian Econ. J. 14(39):61-87.

Hassan, M. K. \& Abdel-Hameed M. B.(2008). “Determinants of Islamic Bankin Profitability,Economic Research Forum". Paper 2, pp 1-32.

Johansen, S. and Juselius, K. (1990). "Maximum likelihood estimation and inference cointegration with application to the demand for money." Oxford Bulletin of Economics and Statistics, Vol.52, pp.169- 210.

Kosmidou, K. (2007). Factors influencing the profitability of domestic and foreign commercial banks in the European Union, Research in International Business and Finance, Volume 21, Issue 2, June 2007, Pages 222-237

Lintner, J. (1965)' The Valuation of Risk Assets and the Selection of Risky Investments in Stock Portfolios and Capital Budgets." Review of Economics and Statistics, 47, pp. 13-37.

Markowitz, H.M. (1959). Portfolio Selection: Efficient Diversification of Investments. New York: Wiley.

Merton, R.C. (1977)"An Analytic Derivation of the Cost of Deposit Insurance and Loan Guarantees: An Application of Modern Option Pricing Theory." Journal of Banking and Finance, 1 (1).

Molyneux, P. \& Thornton, J. (1992). “Determinants of European Bank Profitability: A Note, Journal of Banking and Finance”. Vol. 16, No. 6, pp 1173-1180.

Ngo, P. T. H. (2006), "Endogenous capital and profitability in banking. Australian national University, college of Business and Economics, School of Economics Working Papers, 464, 131-154

Nzotta, S. M. (2004). Money, Banking and Finance (Theory and Practice). 2nd ed, Hudson-Jude Nigeria Publishers.

Rajan, R. G. and Zingales, L. (1998). Financial dependence and growth. American Economic Review, 88, 556-586

Rivard, R. J. and Thomas, C. R. (1997). The effect of interstate banking on large bank holding company profitability and risk. Journal of Economics and Business 49(1): 61-76.

Sharpe, W.F. (1964) "Capital Asset Prices: A Theory of Market Equilibrium under Conditions of Risk." Journal of Finance, 19(3), 1964, pp. 325-342

Somoye R.O.C, D.A Awotundum, Bakare and Kola (2008) capital market reforms and the development of Nigeria's financial sector vol. 6

Staikouras, C., Wood, G.,(2004). The determinants of European bank profitability. International Business and

Economics Research Journal, 3 (6), 57-68. 
Vong, A. P. I. \& Anna, P. I. (2009), Determinants of Bank Profitability in Macao. Macao: University of Macao Press.

The World Bank. (2015). Bank Capital Adequacy Ratio (\%), Return on Asset and Non-Performing Loan| Data |Table. [online] Available at: http://data.worldbank.org/indicator/FB.BNK.CAPA.ZS [Accessed: 23 Dec. 2015 ]. 